\title{
VISIBILITY OF THE VISIT OF POPE FRANCIS IN ROMANIA AS ENSURED IN THE ONLINE ENVIRONMENT
}

DOI: http://dx.doi.org/10.18509/GBP.2020.81

UDC: 272-732.2Francis, Pope (498)

\author{
Vasile Pop ${ }^{1}$ \\ Camelia Teodorescu ${ }^{2}$ \\ Laurențiu Szemkovics ${ }^{3}$ \\ Andrei Ducman² \\ Irina-Valentina Rădoi ${ }^{2}$ \\ ${ }^{1}$ St. Elefterie Church, Bucharest, Romania \\ ${ }^{2}$ Faculty of Geography, CAIMT (Research Center for Integrated \\ Analysis and Territorial Management), University of Bucharest, Romania \\ ${ }^{3}$ National Central Historical Archives, Bucharest, Romania
}

\begin{abstract}
The research proposes itself to identify the attitude of the people in the online environment regarding the visit of Pope Francis in Romania, but also the level of interest expressed by them in the posts distributed on Facebook before, during and after the event. The interest expressed by the people in the online environment was analyzed by the number of likes, distributions and comments offered for the posts containing the keyword "Pope Francis". The main objective of the research is to make a comparison of the impact corresponding to each of the three temporal categories (before, during the event, post event). The secondary objective of the research is to identify the attitude of the people in the online environment in the three stages mentioned above, due to the fact that the public opinion is extremely oscillating, being able to be influenced by the way the event takes place. The database was created through a single social network, namely Facebook, where the number of posts in the analyzed period was very high due to the cultural and historical significance of the event. The motivation of the research was offered by the extremely high interest expressed in the online environment by people, but also by the fact that most of the population of Romania is of Christian - Orthodox religion. The results prove to be another reinforcement of people's interest in this event, regardless of religious affiliation, and the event itself is a balancing element between the two categories of Christians, as people are aware of the immense potential of this visit, both spiritually, financially, able to promote or develop the relationship between Catholics and Orthodox. The event represented an element providing added value to the country's economy, the local economy within the communities visited by Pope Francis, also generated a cultural plus, but also a huge supplementary impulse in promoting the country internationally. After having observed the immense interest shown by the people through direct participation or in the online environment, we could conclude that the cultural-religious pluralism in Romania represented a plus for each group of people taken into consideration, but also at the state level.
\end{abstract}

Keywords: religion, online environment, Pope Francis, Christian community 


\section{INTRODUCTION}

Once with the occasion of Pope Francis's visit to Romania, the entire Christian community in the country presented a special interest in the wonderful event [2], [5], [6]. We cannot deny the full significance of the event, one of economic, religious, as well as tourist nature [1], [3], [16], [18]. Also, the online domain has represented an incredible trampoline for promoting and describing the special event, both for increasing traffic within the online press and for determining writing news on a constant basis [15], [11], [10], [4]. At the same time, the importance of this meeting can be visualized by the fact that the "Adevărul" journal took live images offered by the TVs, especially for the Christians who wanted to view the event in real time, without staying in front of the television. In this research, we relied on analyzing three Facebook pages from different sectors [7], [8],[14]. The three pages mentioned above are the page of the journal "Adevărul", the page of the "Roman - Catholic Archdiocese" of Bucharest, which permanently ensures the information of the Catholics about the news, as well as the Facebook event especially dedicated to the Pope's visit to Bucharest, entitled "Pope in Bucharest". In the pre-event periods, post-event periods, as well as during it, there were numerous posts on these pages, posts that became the main topic of the research [9], [12], [18]. We want to identify exactly what kind of posts have generated the most reactions, comments and distributions, the period when the traffic was the most intense, the page that showed the most intense interest from people, as well as what the reactions of people in the different posts were [9], [12], [13], [17].

\section{METHODOLOGY}

In order to acomplish this research, a single social network has been used, namely the Facebook platform. The main sources of data collection were represented by the pages of the online newspaper "Adevărul", the official page of the "Roman - Catholic Archdiocese" of Bucharest, but also the online event for notifying people about the visit, "Pope in Bucharest". The data extraction was performed on several criteria, namely: the page that offered the posting, the date of posting, the period of posting (pre, during, post), type of posting, number of reactions, number of comments, number of distributions, weight of negative comments, the type of negative comments, but also the number of views of live sessions. The analysis has been performed on three periods: the pre-event period (1 May - 30 May), during the event (31 May - 2 June), but also the post-event period (3 June - 30 June). Also, the type of posts was extremely relevant, there were news about the events, special articles, about the personalities within the event, live sessions, promotional posts, promotional posts for organizers and volunteers, promotions of the main sponsors, and many more details. During the data extraction, a total of 187 posts were extracted from the three chosen pages.

\section{RESULTS}

By analyzing the three figures, mentioned above, we could discuss the importance of promotion, an aspect signaled by the large number of reactions of visitors towards the page of the Roman - Catholic Archdiocese of Bucharest, regarding the posts that had the character of promoting the event, organizational informative messages, as well as in the posts in which RCAB (Roman - Catholic Archdiocese of Bucharest ) wanted to thank the page visitors. The maximum point of reactions was recorded by the announcements regarding the places of organization and organizational information during the pre-event 
period (394 reactions). Looking at the distributions we could again emphasize the desire of the people to express their interest in the event, the desire to further promote the event, as well as to strengthen the power of faith. The maximum distributions were recorded by program information (55), a promotion video (52), and the announcement regarding the time when Pope Francis was shedulled to arrive in Romania. The period during the event presented an intense traffic, in which 7 out of 9 posts recorded reactions from over 115 people (figure 1). Also, the only live stream session realized by ARCB recorded 1200 views, so we can deduce the importance of television and online media in this sector. Surprising is the fact that during the whole period analyzed the number of comments was insignificant, there were many posts in which no comments were recorded, and the posts that received comments were generally questions about the registration (in the pre-event period), but also thank you messages to the team of volunteers, or tributes to Pope Francis (figure 2).

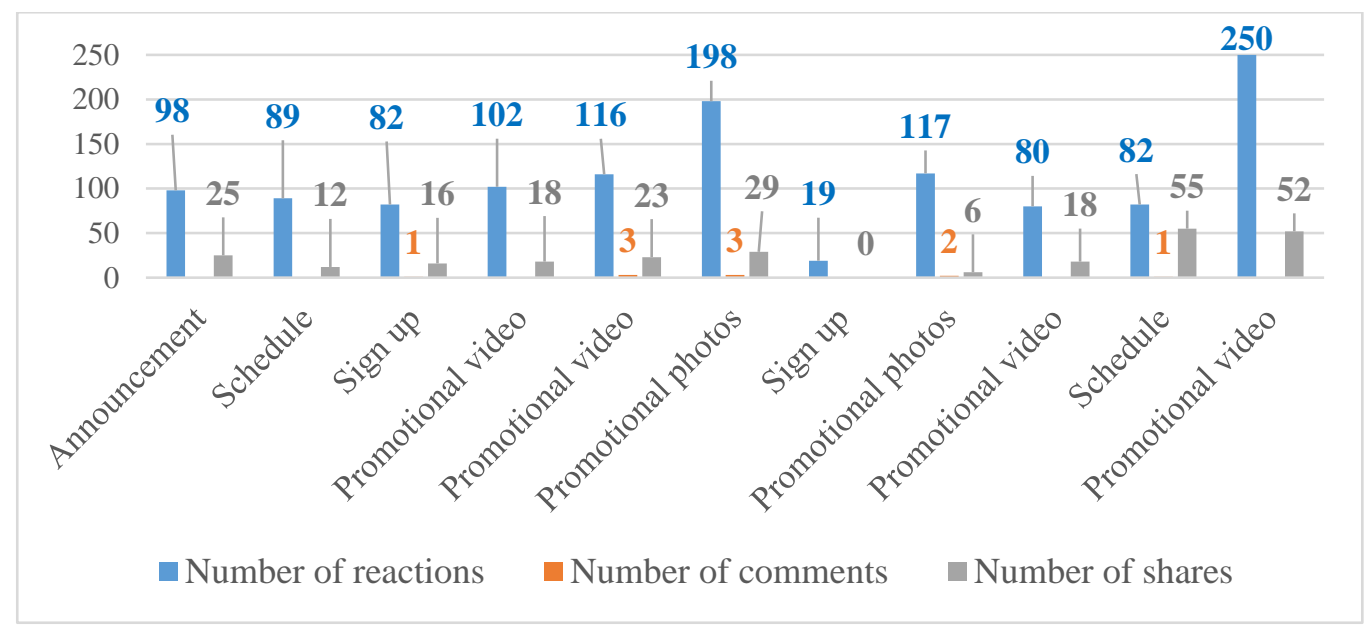

Figure 1. Number of reactions, comments and distributions by type of posting, during the pre-event period (Romano - Catholic Archdiocese of Bucharest)

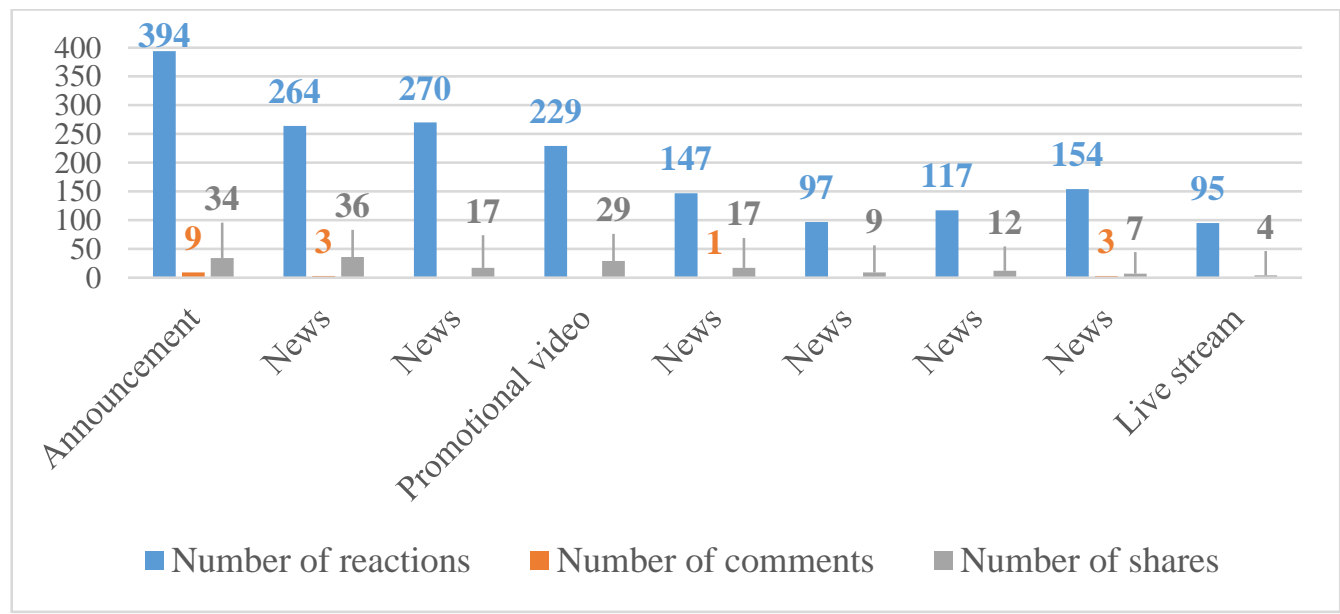

Figure 2. Number of reactions, comments and distributions by type of posting, during the event (Romano - Catholic Archdiocese of Bucharest)

An important first comparative aspect is that the trafic recorded by the "Pope in Bucharest" event is higher than that of the official page of the Roman-Catholic Archdiocese of Bucharest, reaching record values up to several thousands (figure 3). The photos from the St. Joseph's Cathedral represented the main area of interest for the visitors 
of the page, so 423.95 likes per photo were recorded (figure 4). Also, the photo collages during the event were equally appreciated, recording an average of 905 reactions. However, people were extremely receptive to Pope Francis' interview about coming to Romania, posted during the pre-event period (1721 shares) (figure 5).

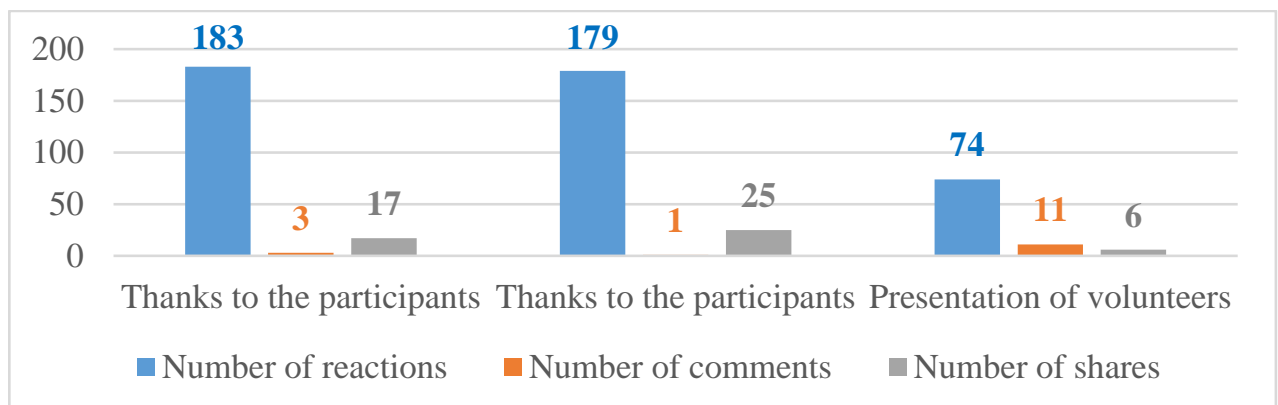

Figure 3. Number of reactions, comments and distributions by type of posting, during the post-event period (Romano - Catholic Archdiocese of Bucharest)

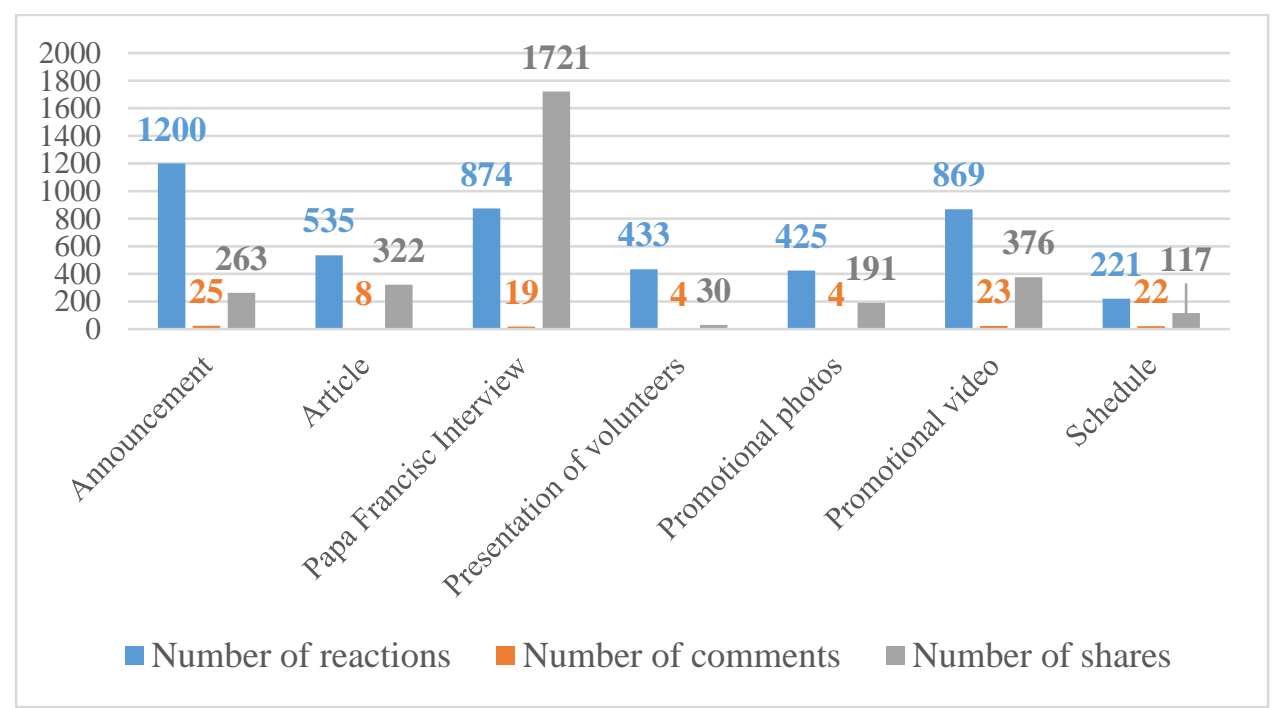

Figure 4. Number of reactions, comments and distributions by type of posting, during the pre-event period ("The Pope in Bucharest" Event)

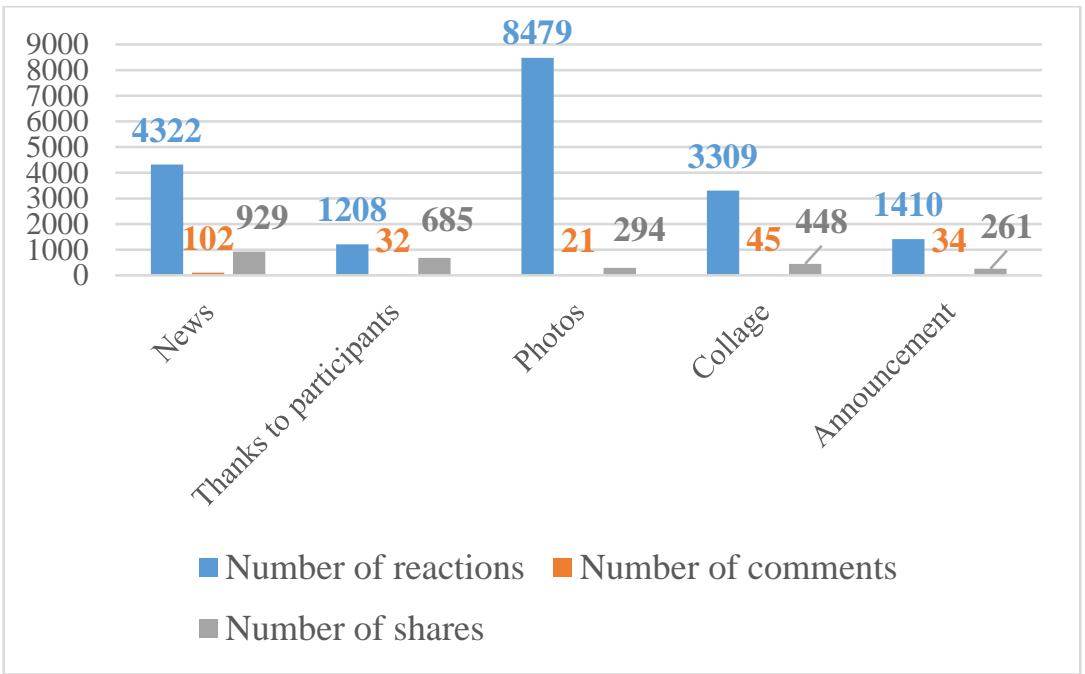

Figure 5. Number of reactions, comments and distributions by type of posting, during 
Also, people showed interest in the news during the event, pointing out that the number of participants could be much higher than the recorded one. An interesting aspect is that people's interest in the event decreased considerably during the post-event period, an aspect easy to notice by the only 117 reactions provided by visitors in the photos posted after the event was completed. Compared with the posts meant to thank the sponsors, we could see a nearly 4 times smaller number of reactions. However, an important new element to offer is the fact that visitors have shown more interest in the post-event period than the pre-event (figure 6) the event ("The Pope in Bucharest" Event)

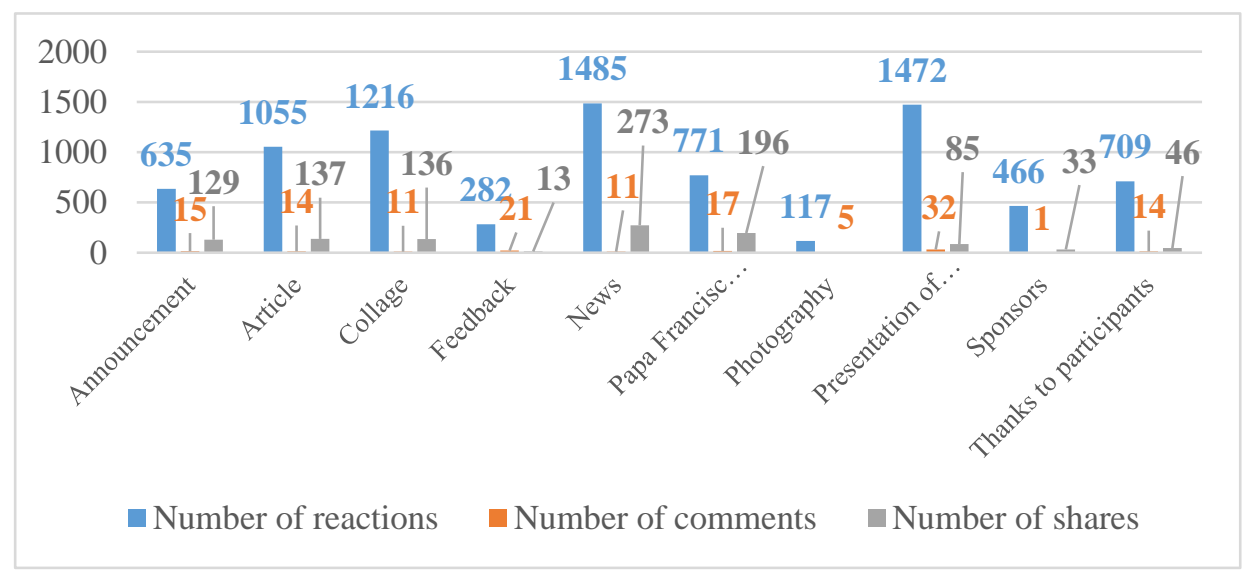

Figure 6. Number of reactions, comments and distributions by type of posting, during the post-event period ("The Pope in Bucharest" Event)

In the postings on the Adevărul journal we find new types of posts: thanks to the participants expressed by Pope Francis, interviews with different personalities of Romania, video reports and different editorials, political news related to the event, as well as live streams. "Adevarul" meant a real pole of live image broadcasting due to the fact that it recorded over 406,000 views, and an average of 23,882 views/live.

Also, the reports about the 7 bishops who were beatified by Pope Francis at Blaj have benefited from considerable interest from readers. The pre-event period did not present a large flow of readers, one similar to the one of the pre-event period on the page of the Roman-Catholic Archdiocese of Bucharest. Live streams have benefited from intense promotion from viewers, distributing live sessions in Facebook groups related to Catholicism and Greek Catholicism. Also, the readers received negative posts about the political personalities in Romania who took part in the event, posts in which dominated the reactions "Angry" and "Haha", and the comments aimed to express critics about the newspaper and about political personalities, not only by political nature, but also strictly connected to the event. Within these posts there were negative comments regarding the promotion of political personalities (15\%), negative comments about Romania's infrastructure (21\%), about the organization of the event (31\%), but also posts that bring criticism to the personalities of the Romanian Orthodox Church (25\%), and the remaining $11 \%$ was represented by other reasons. Of course, it is understandable that most comments were recorded in the live stream sessions (3701 comments), as well as in response to the news related to the events (553 comments) (figure 7, figure 8 and figure 9). 


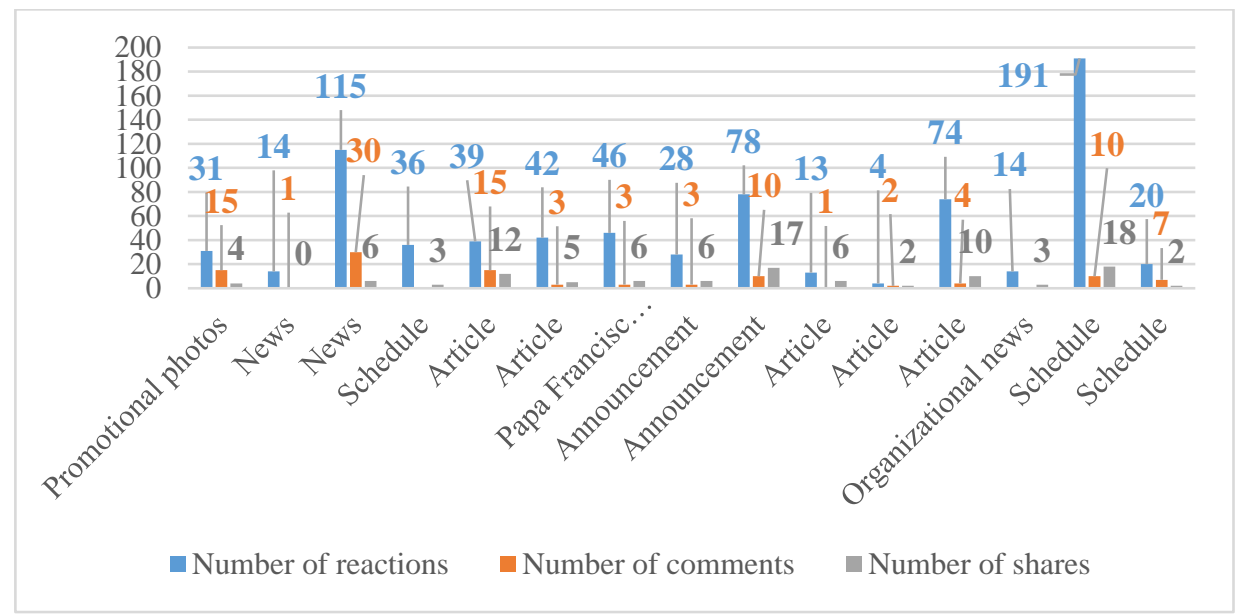

Figure 7. Number of reactions, comments and distributions by type of posting, during the pre-event period ("Adevărul" journal)

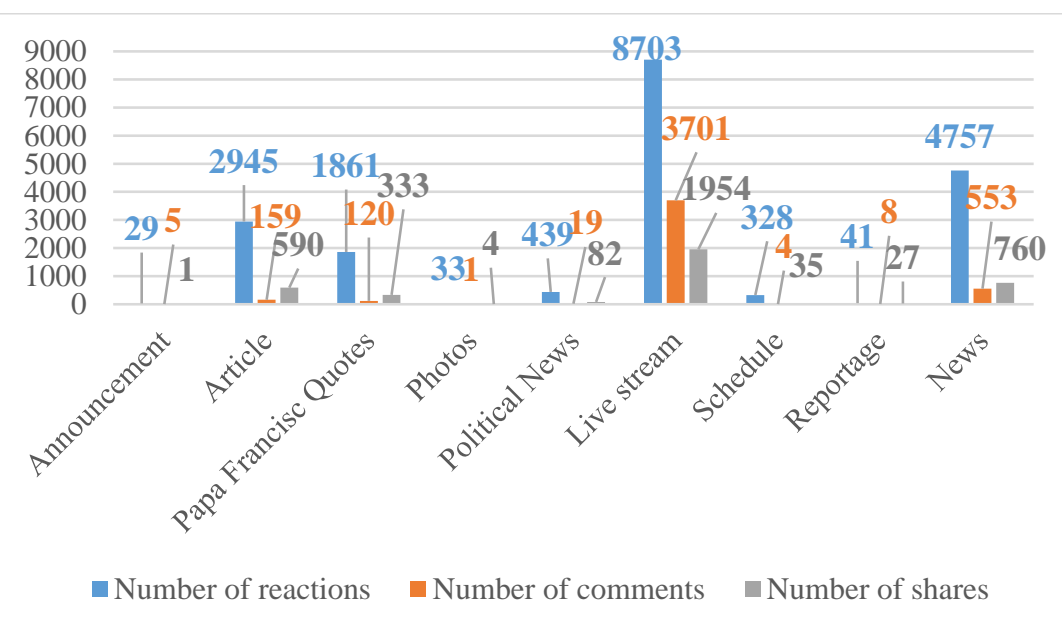

Figure 8. Number of reactions, comments and distributions by type of posting, during the event ("Adevărul" journal)

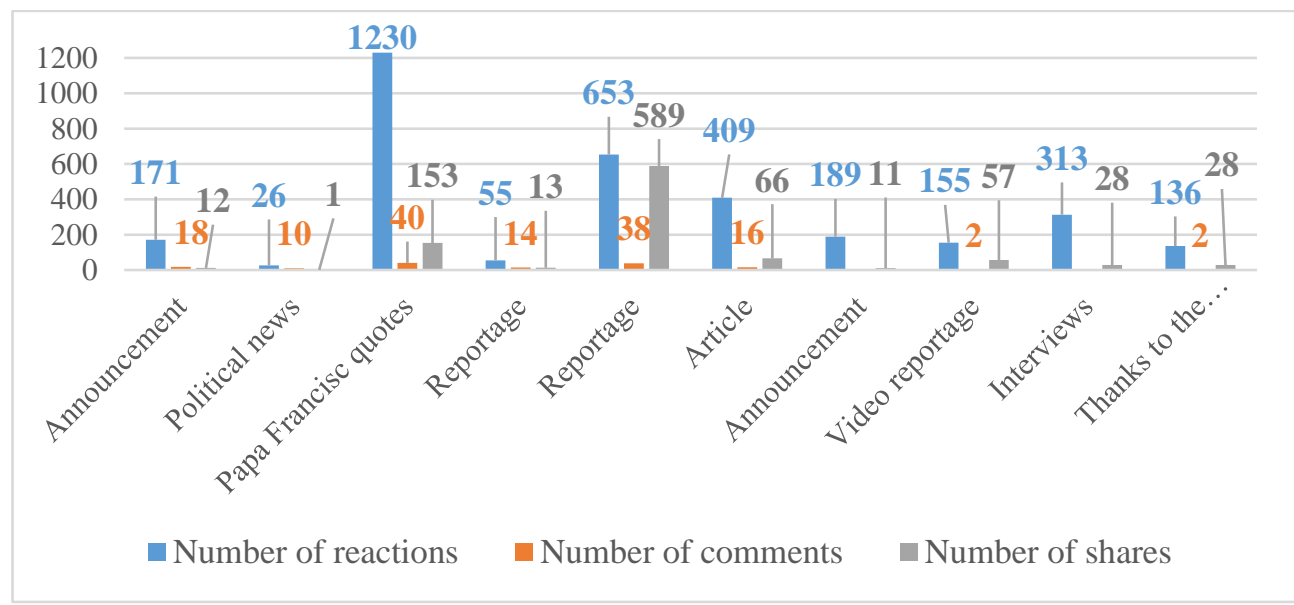

Figure 9. Number of reactions, comments and distributions by type of posting, in the post-event period ("Adevărul" journal) 


\section{CONCLUSIONS}

During the research there were periods when the number of posts and their types increased, so it was necessary to compile them by type of post. The research is relevant to the scientific field due to the fact that it shows us the main methods of increasing the flow of readers during the events, namely live streams, real-time photos posted, collages of photos depicting the central personality of the event, but also interviews with them. We also observe a general tendency of reticence regarding the comments of all three pages, but the number of distributions in their own chronology or in thematic groups is much higher. Another important aspect is the fact that people are much more interested in posts intended for video promotion. Also, the general tendency of all the pages is decreasing with the removal of the event. Valuable for research is also the way in which people received the posts that did not have a religious character, with a general tendency to reject this information. Interesting and extremely valuable for the research is the fact that the readers expressed their dissatisfaction only on the Adevărul page, and there was no negative comment on the RCAB page or the "Pope in Bucharest" event. At the same time, it should be emphasized the increased interest in this event, one not only of a religious nature, but also of an economic, tourist and promotion of unity between Catholicism and Orthodoxy. Last but not least, the importance of the online domain should be highlighted in an event that is not closely linked to social networks through the large number of readers, respondents and viewers on the three pages.

\section{REFERENCES}

[1] Alvarez J.J.,To exist with and for the people: Philosophico-Religious roots and the need of a moral common faith, Politics and Religion Journal, vol.13, issue 1, pp 97-112, 2019

[2] Barrera-Fernandez D., Hernandez-Escampa M., The impact of urban policy in the management of the tourist-historic city: a comparative study, Pasos-Revista de Turismo y Patrimonio Cultural, vol. 14, Issue 3, pp 705-724, 2016

[3] Besschetnova Elena, The idee of Christian Unity at the End of the Nineteenth Century, Church History and Religious Culture, vol. 99, Issue 1, pp. 46-63, 2019

[4] Costa Hilário, Ana Catarina; Marreiro das Chagas, Márcio, Influencia del escultismo en la formación personal y social de los scouts por medio de la práctica del turismo ecológico y pedagógico, Estudios y Perspectivas en Turismo, vol. 23, Issue 3, pp 484-50, 2014

[5] Dietrich Stephanie, God's Mission as a call for Transforming Unity, International Review of Mission, vol.107, Issue.2, pp 378-390, 2015

[6] Dincă Iulian \&Teodorescu Camelia, The Romanian rural space and its landscapes: attraction and motivation for relocating townspeople, Geographia Napocensis, vol. 1, pp 2136,2015

[7] Ghibanu Ionut Adrian, Inter-Religious and Inter-Christian Dialogue - a Contemporary Ecclesial Educational Priority, Revista Romaneasca pentru Educatie Multidimensionala, vol.10, Issue. 2, pp 36-44, 2018

[8] Ghibanu Ionut Adrian, Religious Identity and Multicultural Dialogue in Contemporary Europe, $2^{\text {nd }}$ Central \& Eastern Lumen International - Multidimensional Education \& Professional Development, Ethical Value (MEPDEV), $2^{\text {nd }}$ Edition, European Proceedings of Social and Behavioural Science, vol. 27, pp 234-240, 2017

[9] Herman G.V., Varnav R., Design elements for promoting attraction case study: Tara Oasului museum (Satu Mare County), Geojournal of tourism and geosites, vol. 14 / issue 2, Oradea, Romania, pp 168-177, 2014 
[10] Herms Eilert, The Contribution of the Christian churches to a Culture of Sustenability or: The Christian Culture of Sustenability, Zeitschrift Fur Evangelische Ethik, vol. 62, Issue 2, pp. 115-128, 2018

[11] Hocaoglu D.A., The Role of Design in Cultural Heritage Based City Branding of Beypazari, Milli Folklor, vol. 109, pp 217-232, 2016

[12] Ilieș D.C., Baias Ș., Buhaș R., Ilies A., Herman G.V., Gaceu O., Dumbrava R., Măduța F.M., Environmental education in protected areas. Case study from Bihor county, Romania, Geojournal of tourism and geosites, vol. 19 / issue 1, pp 126-132, 2017

[13] Knop Iulia, The Diaconate as a Dimension of the Diaspora Church, Internationale Kattholische Zeithschrift Communio, vol.1, Issue 3, pp.216-228, 2018

[14] Kopiec Piotr, The idea of the Biblical economics: Utopia or chance in the of the contemporary transformation of the sphere of work, HTS Teologiese Studies-Theological Studies, vol. 75, Issue 4, 2019

[15] Oliver Willem H., Erna, God as One, HTS Teologiese Studies-Theological Studies, vol. 75, Issue 1, 2019

[16] Radu-Daniel Pintilii, Daniel Peptenatu, Ana-Maria Ciobotaru, Sorin George Toma, Ana Maria Grigore, Cristian-Constantin Drăghici, Răzvan-Cătălin Dobrea, Adrian Gabriel Simion, Ion Andronache, Camelia Teodorescu, Daniel Constantin Diaconu, Creative economies in Romania-spatial projections and trends, Bulletin of Geography. Socio-Economic Series, Vol. 37. pp 95-108, 2017

[17] Teodorescu Camelia, Octavian Teodorescu, Nicoleta Bira, Badea Alin, Badea Livia Florina, Religious and cultural tourism and the socio-economic and educational implications, Quaestus Multidisciplinary Research Journal, vol. 8, pp 227-285, 2016

[18] Teodorescu Camelia, Radu-Daniel Pintilii, Peptenatu Daniel, Teodorescu Octavian, Toma Sorin George, Popularizing Cultural Identity Through Religious Tourism-Socio-Economic and Educational Implications, International Multidisciplinary Scientific GeoConference: SGEM: Surveying Geology \& mining Ecology Management, vol.3, pp 947-954, 2016 